\title{
Historical Studies on Sarak Values and their Implementation in Gowa
}

\author{
M. Dahlan M \\ Lecturer at Faculty of Adab and Humanities, \\ Universitas Islam Negeri Alauddin, Makassar, Indonesia
}

Doi:10.5901/mjss.2017.v8n3p183

\begin{abstract}
The study examined historical sense of sarak values and their implementation in Gowa, including the concept of sarak as a part of pangngadakkang element, Gowa people's understanding about sarak as pangngadakkan element, and the implementation of sarak values among Gowa people. This is a qualitative descriptive research implementing field research method. In order to find out the actualization of sarak in Gowa, it also used historical approach as the main method in the research. The data obtained in this study were processed and analyzed in a deductive, inductive, and comparative way. The study found out that sarak is Islamic law as well as pangngadakkang element which is determined after Islam exists and is accepted by the people of Gowa. The implementation of sarak in Gowa is loaded with intellectual, moral, social, and ritual values. Spiritual values related to humanism contain aspects of the sanctity of life. Intellectual value is found in the history that in the era of Gowa Kingdom local people have reached high intellectual capacity. The teachings of sarak also set social values which mainly include on procedures of men relation in the law of family and muamalah. Ritual value is also the most prominent aspect as reflected in palili and attumate ceremony. The research indicated the significance of preserving sarak values as the element of pangngadakkang as long as it does not conflict with the teachings of Islam, for it symbolizes identity of a community that has been bequeathed by the glory of the past.
\end{abstract}

Keywords: sarak, sarak values

\section{Introduction}

Sarak becomes a significant element of pangngadakkang as an integral part of culture and tradition in Makassar society, especially in Gowa, which has been entrenched for a long time. Pangngadakkang elements are adék (custom), rapang, bicara, warik, and sarak, which in Bugis society is known as pangngaderreng (Rasdiyanah, 1995).

Pangngadakkang elements, seen from historical perspective, aim to improve the condition of people in the era of Gowa Kingdom. Rapang is to strengthen the kingdom, warik is to strengthen empathy in the kingdom, bicara is the hedge of arbitrary action, and sarak is a back support for vulnerable honest people. It is described in Lontarak Latoa that when adék is not maintained, the people will be uncontrolled; when rapang is not maintained, the kingdom will be weak; when warik is lost, the people will lose their empathy; when bicara does not exist, the family relation will be destroyed; and when sarak is not implemented, everyone will arbitrarily act.

Sarak as Islamic tradition becomes urgent since the inclusion of Islam in the reign of King Gowa 10, Tunipallangga (1546-1565), which is when the king gave permission to the Malay Muslim traders through Nakoda Bonang, to settle at Somba Opu. Almost all religious ceremonies and symbols are run by local people with sarak.

Seen from historical point of view, sarak is all the rules derived from the teachings of Islam assimilated with pangngadakkang, in term of fiqh (Islamic jurisprudence), theology, Sufism, and morals. In other words, besides meddling in the actions and decisions of pangngadakkang, sarak at least gives guidance in accordance with the teachings of Islam.

In connection with previous description and to find out more about the position of sarak in pangngadakkang system for Gowa people, it is very important to investigate sarak which contain spiritual, intellectual, moral, social, and ritual values. Therefore, this study focused on answering several problematic questions: 1) How is the concept of sarak and its implementation as an element of pangngadakkang?; How is the actualization of sarak are in Gowa?; How is the linkage between sarak and pangngadakkang?; and How is the implementation of sarak values for the people of Gowa.

\section{Literary Review}

Sarak is sharia (Islamic law) which becomes an element of pangngadakkang set after Islam is accepted by the Makassar tribe. Sarak contain concepts of the teachings of Islam, which becomes the basis of all aspects of life rituals. Sarak also 
contains various provisions of law which is based on monotheism to Allah (Abdullah, 2005). Another source pointed out that sarak contains the values and the teachings of Islam that has assimilated with the cultures of society since the advent of Islam among them (Mattulada, 2004).

The presence of sarak as one element of pangngadakkang may occur due to the process of acculturation. Abdul Wahab Khallaf explained that in one of the basic conditions of usul figh, it is set out the rules of al-ādat al-muhakkamah or al-âdat syari'at muhakkamah, that is the habits and customs of a society and local culture is the source of Islamic law, while not damaging the faith (Khalläf, 2002). Habits and customs of a society regarded as customary law is the cultural and social system includes ways of someone to behave towards their fellow human beings in a social system before the advent of Islam, and after the entry of sarak that does not break the faith after the arrival of Islam.

\section{Research Method}

This study was conducted in Gowa district as one of the bases of the Makassar tribe and was once a center of Islamic kingdom implementing sarak practice.

Historical approach became the main method in this study in order to find out the actualization of sarak among Gowa people. The data obtained in this study were qualitatively processed and analyzed in a deductive, inductive, and comparative way.

The study is a field research implementing qualitative descriptive method. There are two types of data in this study, primary and secondary data. The data were collected through observation with some instruments and techniques, such as questionnaires and interviews with tribal elders and community leaders in Gowa.

\section{Results}

People in Gowa, South Sulawesi, are mostly Makassar tribes and included into Malay. Those who are Muslims preserve and implement sarak concept in accordance with the teachings of Islam.

The values of sarak derived from the teachings of Islam have undergone a process of the acceleration of culture and customs. Therefore, in addition to enriching pangngadakkang system, sarak also sifts and filters things which are not in line with sarak values implicitly. For example, in the past there was a pangngadakkang tradition done by Gowa people called palili, held for 40 days once a year as a sign to start cultivating rice. The tradition, said Makassar people, is a part of religious rituals.

Based on the results, the ritual has been simplified, especially after the shift of governmental system from imperial system into a unitary state. Formerly the event was held in 40 days and nights. After the shift, it is conducted in seven days and nights. However, in rural areas, such as Tombolopao, Biringbulu, and Malikaji, whose territory bordered with Sinjai, the ceremony by their tradition is still carried out, according to the survey, solely in one night. In urban areas and the surroundings, such as in Sungguminasa, Pallangga, and Barombong, the ceremony is no longer carried out.

The cause of the shift in palili, based on the research, is due to two factors, the change of governmental system and pangngadakkang system which has been acculturated with the teachings of Islam.

The values of sarak, implemented by Gowa people, are described as follows:

\subsection{Spiritual Values}

The root of word "spiritual" comes from "spirit", that is of the strong stimulus from self. Terminologically, it can be interpreted as innate religious stimuli or religious impulse. This is in line with the Word of God in the Qur'an, surah al-Rum 30:

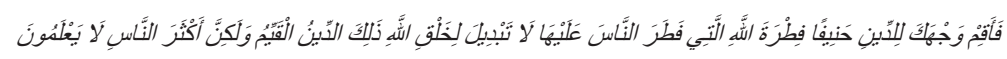

Translation:

"So set you your face truly to the religion being upright, the nature in which Allah has made mankind, no change (there is) in the work (wrought) by Allah, that there is true Religion, but most among mankind know not."

فطرت اله (the nature of God) in the above verse is interpreted that man was created by God with a religious instinct, which is the religion of monotheism and to believe in the religion of monotheism and practice its teachings. 
The spiritual values related to the nature of humanism contain aspects of the sanctity of life who believe in the existence of sawwa dewata, Karaeng, and after the advent of Islam it is called Karaeng Allah Ta'ala. Therefore, Gowa, as the first Kingdom that accepts Islam, made it the religion of the kingdom. Any action taken by the government must be based on Islamic teachings. This spiritual value is clearly stated in Makassar lontarak philosophy and is also found in the Book of Kelong Makassar which states that:

Mammuji mma' inakke, Mappibuang ri Batara, kundo'do puli, menynre'ang ri nia'na, mallako ri Allah Ta'alah, parentai taua ri ero'na, ... moterekko ri appaka sulapa na ammoterekko ri battanna kalennu maknassa niya atu anjoreng pangngassengan napadongkok Allah Ta'alah.

\section{Translation:}

I only praise, surrender to Allah, surrender, to His oneness, be pious to Allah, order people based on their sincerity, ... discover the four corners and come back to you because in yourself there is science placed by Allah Ta'ala.

The above sentence contains a very high spiritual value, gives encouragement (spirit) to be pious and do all the commandments of religion with sincerity. Appaka sulapa found in Iontarak is also called Sulapa' Appa' (rectangular) which philosiphically refers to a return to the identity element of human creation (nature) formed of four elements, namely earth, water, fire, and air.

The philosophy of sulapa appak greatly influences the spiritual value for society in Gowa because the philosophy is in line with the beginning of surah Al-Rum verse 30, فأقم وجهاك للاين حنيفا فطرة الله (So set you your face truly to the religion being upright). In this case, people perceives the universe horizontally and vertically as depicted on the four winds the West, East, North, and South as a place to expose the self to see the greatness of God. It contains a spiritual value to make people believe in the greatness of Allah and make them have the spirit to keep devoting themselves to Him.

\subsection{Intellectual Values}

Many verses contain intellectual values, even the first revelation, "قٕ!" increase their intellectual capacity. Similarly, other verses also use terms such as afalā ta'qilūn, ${ }^{1}$ afalā tubșirūn, ${ }^{2}$ afalā yanzurūn, ${ }^{3}$ and many more to show the significance of intelligence. In line with that, God places intellectuals at a high position and human is the only creature given intelligence to be used in good way based on faith and devotion to God. ${ }^{4}$

To improve the intelligence, seen from historical perspective, the leaders of Gowa, such as Karaeng Pattingalloang, are people who have high intelligence, master all the secrets of Western science, learn the history of European empires, read science books days and nights, and speak Portuguese till people expected that they are Portuguese.

Besides, history recorded that in the reign of Sultan Malikussaid in 1639-1653, Gowa society reached the peak of intellectual glory because at that time there were already tools, like telescope, used by the King of Gowa, books written by Karaeng Pattingalloang were widely spread containing intellectual spirit. Similarly, in the Book of Kelong Makassar, it is found wise word as well as pappasang (message) for present and future generations to enhance their intelligence (Hakim, 2006):

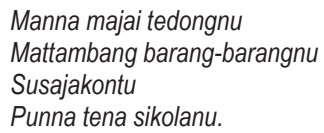

Translation:

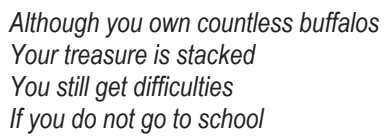

${ }^{1}$ See, for instance, surah al-Baqarah: 73, 242; surah Ali 'Imrān: 118; surah al-Mu'minun; 80

2See surah al-Qașaș/28: 72; al-Zukhruf: 51

'See surah al-A'rāf/7: 185; surah Qāf: 61.

${ }^{4}$ See surah al-Mujādalah: 11 
The wise words contain intellectual values with sarak. It gives a moral message about the urgency of studying to improve the intellectuality by concentrating on education through schools. In Pappasang, it is also mentioned that,

Punna "boyako pangngassengngan warakko rolong, punna tena iwarak timborokko punna tenatimboro, anraikko puna tena iraya kalaukko napunna tena ri appaka sulapa ammoterekko ri battanna kalennu maknassa niya atu anjoreng pangngassengan napadongkok Allah Ta'alah (Tika, 2007).

\section{Translation:}

If you are looking for science, go to North first. If you do not find it in North, go to South. If you do not find it in South, go to East. If you do not find it in East, go to west. If you do not find it in the four winds, return to yourselves because there is science in the person placed by Allah Ta'ala.

The Pappasang is relevant to the expression of the Prophet "go look for science to China", meaning that wherever you go in order to increase the intellectuality, it is highly recommended, as such has been done by the ancestors of Gowa people. It is also recorded that Tuanta Salamaka Syaikh Yusuf al-Makassari has traveled the world to seek knowledge.

\subsection{Social Value}

The teachings of Islam contain social value. It can be seen from the content of the Quran that affirms human condition in a social environment with their various tribes and nations forms a social life, makes them help one another in goodness, and reminds that human happiness is also connected to their good relation with neighbors. As the result, the differences in ethnicity, race and nation might generate cultural differences among them.

In this case, sarak also presents to regulate the law of kinship and muamalah, even in the framework of social issues, and political law of social government (al-fiqh al-siyasi wa al-dusturiyah). Political law of social government, in this case, established sarak council in the kingdom which aims to regulate all religious issues including Islamic education in the sense of duty to give guidance and counseling on Islamic affairs to the community.

Sarak council in Gowa historically was formed after Islam became the official religion of the empire. During its development, the council was included in the structure of kingdom called Daengta Kaliya. Daengta Kaliya organized the religious proselytism and the practice of the teachings of Islam in all aspects of life such as marriage and inheritance and the maintenance of houses of worship, and served in an official ceremony of vow with the Quran in the Kingdom.

Daengta Kaliya also served as a missionary, teacher, and main supervisor in teaching Islam to the people assisted by the operational executor of the bureaucracy at local level empire called Daeng Imang, Gurunta, Hatte and Bidala.

\subsection{Ritual Value}

Ritual value is the most prominent part of sarak aspects. For example, in the past it was written by Shaf Muhtamar that in Gowa there is a tradition called palili, held for 40 days once a year as a sign of starting work for cultivating rice. The tradition, said the Makassar at the moment, is part of religious rituals (Muhtamar, 2007).

Based on the results, the ritual has been simplified, especially after the shift of governmental system from imperial system into a unitary state. Formerly the event was held in 40 days and nights. After the shift, it is conducted in seven days and nights. However, in rural areas, such as Tombolopao, Biringbulu, and Malikaji, whose territory bordered with Sinjai, the ceremony by their tradition is still carried out, according to the survey, solely in one night. In urban areas and the surroundings, such as in Sungguminasa, Pallangga, and Barombong, the ceremony is no longer carried out.

The cause of the shift in palili, based on the research, is due to two factors, the change of governmental system and pangngadakkang system which has been acculturated with the teachings of Islam.

First factor is the change in the state system from imperial system into a unitary state. The role of the king, who has authority and broad knowledge about the customs, is now replaced by the role of regent, district head, or village head concerning more in the development of society in terms of economic growth by thinking effectiveness and any aspects. In this respect, palili is deemed as an old pattern that could hamper economic growth because it takes a long time, i.e. 40 days and nights, and obstruct other activities which are more significant. In addition, it spends a lot of budget, which should be provided by government, or in the past provided by the kingdom.

The source of funding of palili, which is carried out in seven days and nights, still comes from the government. Up to this moment, for the ceremony is nongovernmental, it is simply held in one night. The budget allocated by the government is decreasing year by year. This is supported by the absence of regents and district heads, unlike palili in the 
past which was attended and officially opened by the king or local traditional authorities that were appointed.

The second factor is the nuance of sarak in pangngadakkang. In this respect, the procession which is punctuated by appanaung kaddokang (serving food) and accerak (slaughtering) is one of the activities which is not beneficial based on sarak. Furthermore, many intellectuals in this area who really understand about religious teachings assume that giving offerings with appanaung kaddokang and accerak has infringed the rules of sarak which can even bring on idolatry.

Adak institution, the old habits of traditional community in Gowa regarded as pangngadakkang system, is increasingly getting eroded since it is deemed to bring polytheism. Many events in the world of agriculture (such as palili) and in everyday life that was once considered sacred and understood as part of a ritual are forgotten and left because they violate sarak. It can be seen, for example, in mortality institution here there is no customary rules stating that certain ceremonies should be held that commemorate the third day, the seventh day, the fortieth and so on, after the death of a person. However, because most religious scholars argued that it is not useful, now people generally carry out the funeral ceremony Makassar in accordance with the teachings of Islam. After the burial, the family holds the event of ta'ziah (a visit of condolence) and after it ended the attumate (death).

\section{Conclusion}

The values Sarak derived from the teachings of Islam in Gowa have undergone a process of acceleration of culture customs. It can be said that in addition to ensuring the system of pangngadakkang, sarak on the other hand also filter and reduce the system of pangngadakkang, because apparently most the systems are not in line with the values of sarak.

The implementation sarak loaded with intellectual, moral, social, and ritual values. Spiritual values related to humanism contain aspects of the sanctity of life and believe in the existence of sawwa dewata, Karaeng, and after the advent of Islam it is called Karaeng Allah Ta'ala. Therefore, Gowa, as the first Kingdom that accepts Islam, made it the religion of the kingdom. Any action taken by the government must be based on Islamic teachings.

Intellectual values are found in the history that in the era of Gowa Kingdom local people have reached the summit of intellectual glory. Social values mainly concern on procedures relating to relation of men in the law of kinship and muamalah which has been set by sarak. Ritual values are the most prominent aspect of sarak in the form of religious rituals such as palili and attumate. The research indicated the significance of preserving sarak values as the element of pangngadakkang as long as it does not conflict with the teachings of Islam, for it symbolizes identity of a community that has been bequeathed by the glory of the past.

\section{References}

Al-Qur'ān al-Karīm

Abdullah, A.H. (2005). The Bugis Makassar; An Overview Of Patterns of Behavior and Human Worldview Bugis-Makassar. Jakarta: Inti Idayu Press.

Barakatuh, A.R. (2000). "Pappasang Tau Toa "in the module Node Democracy Education Program Jeneponto South Sulawesi. Makassar: Indonesian Community for Democracy (KID) in collaboration with the Netherlands Institute of Multiparty Democracy (NIMD).

Farḥān, I.A.(2003). Al-Tarbiyah al-Islāmiyah bayn al-Așālah wa al-Ma'āșirah. Edition II; t.tp: Dār al-Furqān.

Hakim, A.H. Al-Bayān fiy IIm Ușūl al-Figh. Bandung: Maktabah Dahlan, t.th

Hakim, C. (2006). Kelong Book Makassar. Sungguminasa: Gora Pustaka Indonesia.

Kawu, A.S. (2007). The story of the story of Wise People Sulsel. Makassar: Pustaka Repleksi.

Khallâf, A.W. (2002).Ușūl al-Fiqh. Bairüt: Dar al-Maktab al-Așriyah.

Kulle, S. Tika, Z., and Najamuddin.(2007).Gowa in Turmoil; People's Movement Against Invaders. Makassar: Yayasan Butta Gowa with the Institute for Research and Cultural History Writing South Sulawesi.

Matthes. (1992).Makassaarche Chrestomathie. Amsterdam: Gedrukt ED.

Mattulada. (2004). The traces Makassar and Islamicpresences, in history. $2^{\text {nd }}$ Edition. Ujung Pandang.

(1999). Latoa; A Political Anthropology Painting the Past. Makassar: Ininnawa.

(1998). History and Culture of South Sulawesi. Ujung Pandang: Hasanuddin University Press.

Muhtamar, S. (2007).Future Cultural Heritage Luhur Sulsel. Makassar: Pustaka Refleksi.

Munada, A. (2005). The bureaucratic behavior of Makassar society. Dissertation. Makassar: PPS Hasanuddin University.

Rasdiyanah, A. (1995). "System Integration System Pangngadereng with Shari'a as Worldview Bugis in Lontarak Latoa". Postgraduate Dissertation. Yogyakarta: PPS IAIN Sunan Kalijaga.

Sewang, A.M. (2005). The Gowa's Kingdom Islamization. 2nd Edition; Jakarta: Yayasan Obor Indonesia.

Syalțūt, M. Al-Islam; Aqidah wa Syari'ah. 3rdEdition; t.t.: Dar al-Kalam, 1966.

Tika, Z.(2007).Lontara Mangkasara Sign Interwoven Big World. Makassar: Pustaka Repleksi.

(2002). Makassar in Lontara; In the past your history. Makassar: Pustaka Refleksi. 
(2006). dan M. Ridwan, Rosdiana Z, Profile Kings of Gowa. Sungguminasa: Perusda Karya Gowa.

Editor Tim of the Pustaka Refleksi. (2003). Siri and Pesse; Human Dignity Bugis, Makassar, Mandar, Toraja. 2nd Edition; Makassar: Pustaka Refleksi.

Wahid, S. (2008). Human Makassar. $2^{\text {nd }}$ Edition; Makassar: Pustaka Refleksi. 